\title{
Police violence as punishment: Does excessive use of force serve to punish those who threaten status and power hierarchies in society?
}

Monica M. Gerber, Universidad Diego Portales

Ismael Puga, Universidad Central

Cristóbal Moya, Bielefeld Universität

Francisca Gomez Baeza, University of Washington

Jonathan Jackson, London School of Economics and Political Science

Javier Herrada Marambio, Observatorio Social, Ministerio de Desarrollo Social y Familia

Sofía Montedónico, Subsecretaría de Prevención del Delito, Ministerio del Interior

\section{Acknowledgments}

This research was partly funded by the Center for the Study of Social Conflict and Cohesion, COES, ANID/FONDAP/15130009.

\begin{abstract}
Objectives

Why do some people view excessive police violence as acceptable? We reason that excessive police violence not only seeks to control crime, but also to punish criminal offenders. We propose the concept of police violence for punishment and explore its associations with different forms of punishment and punishment motivations. We reason that some people support excessive police violence to reinforce status and power hierarchies with minority groups.
\end{abstract}

\section{Method}

We draw on data from a representative sample of adults living in Chile conducted in $2015(\mathrm{n}=1,302)$. We use structural equation models to predict support for police violence for punishment, legal and extra-legal violence.

\section{Results}

Police violence for punishment was strongly related to support for extra-legal punishment. Punitive police violence and extra-legal punishment were both predicted by the motivation to restore status and power relationships, followed by deterrence. In contrast, norm restoration was the main predictor of legal punishment. Police violence for punishment was significantly less supported by ethnic minority members.

\section{Conclusions}

We conclude that police excessive use of force can usefully be understood as police violence as punishment. We discuss the extent to which police repression is perceived to restore status and power hierarchies threatened by crime. We conclude that reducing police violence requires a political and cultural process well beyond reforming police protocols and procedures. Working towards more horizontal relations between police officers, citizens and minority groups should reduce perceived needs to restore power and status relationships, hereby reducing support for police violence as punishment.

Keywords: Police violence, punishment, social control, ethnic minorities 


\section{Introduction}

The capacity of the police to assert, enhance and reproduce order, deal with crime and protect the populations they serve depends on the capacity to use force to achieve these ends - whether this means restraining someone attempting to rob a store or shooting an armed offender. Part and parcel both to effective policing and public support is the recognized power to forcefully attend to diverse matters and inflict sanctioned violence as part of their duties. Yet, while the potential to use force might be necessary to the role and authority of the police, police officers can - and often do - use violence that exceeds the reasonable and proportionate amount required to control a situation and/or effectuate an arrest. The latter is especially problematic when people from different minority groups, demonstrators and dissenters, or any group in a disadvantaged position are disproportionately more likely to have force used against them by police officers. Excessive police violence directed towards minority groups is receiving an increasing amount of social, political and media attention in countries across the world. The Black Lives Matter (BLM) movement has shown light on the disproportionality in police use of fatal force against Black Americans and elsewhere. A recent USA-based study estimated that police were three times more likely to use fatal force against Black people compared to White people (Schwartz \& Jahn, 2020). There is an urgent need to not only understand why such excessive police violence happens against certain groups, but also what can be done about it.

Movements such as BLM have brought into sharp focus the role of public attitudes towards excessive police violence and unjustified use of force. When police officers repress minority group members they step outside of the boundaries of what can be considered legal use of violence, and this violation of due process shows disrespect towards minority group members and further reinforces oppression and the maintenance of their disadvantaged position (see Gerber \& Jackson, 2017). When significant numbers protest against the kinds of police violence that they view as unacceptable, this can create political pressure, which has the potential to help shape policing policy and practice. The potential of public opinion to question police use of force makes it critical that we understand the underlying psychological dynamics of support for different types of police violence. Why and under what conditions do some people view excessive police force as acceptable?

In this paper we propose a new perspective on public support for police violence based on the idea of police violence as punishment to those who threaten status and power hierarchies in society. Drawing on data from a nationally representative sample survey of Chilean adults, and bringing into perspective prior research into punitiveness and motives to punish criminal offenders, we look at how public support for police violence relates to different forms of punishment (legal and extra-legal punishment) and to different motivations to punish. We distinguish between police violence for social control (minimum necessary, reasonable violence according to previous conceptualizations) and police violence for punishment (excessive violence, where police punish alleged offenders in ways that either side-step or go beyond their legal duties). We argue that approval of some forms of police violence can be viewed as support for an extra-legal form of punishment that is rooted in the motivation to restore the status and power hierarchies that have been threatened by crime and alleged offenders. In short, we contend that some people support excessive police violence against certain out-groups to deny the right to procedural justice and due process, humiliating and denigrating them (Gerber \& Jackson, 2017).

We focus on Chile, a country with a long history of police repression to ethnic minorities and political dissenters. The main militarized police force, Carabineros, played an important role in the military Junta taking power during Pinochet's dictatorship (1973-1989) and in numerous atrocities especially during the first years of the dictatorship. By the end of the dictatorship, public knowledge of some of these cases meant that they suffered a deep legitimacy crisis (Dammert, 2009). After the transition to democracy Carabineros managed to increase its public standing, although this seems to be due more to successful communication strategies and a growing fear of crime than policy changes regarding citizens' rights (Bonner, 2013). Hathazy (2013) describes the doctrine of the Chilean police as a mix of neoliberal management and counterinsurgency principles applied to common crime and social disorder. Such doctrine, combined with extreme bureaucratic autonomy and a strong public image has enabled Carabineros to resist reform so far (Bonner, 2013). Killings by the police remain common in Chile (Bonner, 2014), torture is an ongoing practice in police stations (Fuentes, 2005), and other types of excessive police violence have persisted, perhaps even increased over time (Dammert, 2009). 
Police repression has been particularly tough against the Mapuche people. The Mapuche are the largest group of indigenous inhabitants of the southern and central region of Chile. They correspond to almost 80 percent of the indigenous population in Chile, and about 10 percent of the total population. Since Chile's independence, Mapuche people have seen their land reduced and have been confined to small reservations. The long political conflict between the Chilean state and Mapuche communities has steadily escalated since the 1990s, with Mapuche lands being constantly occupied by a heavily militarized police force (see Gerber et al., 2018). The use of excessive force is particularly evident, with several killings during the last years and many reports of violence against children prompting varying levels of social outrage. Racism against the Mapuche, economic interests by forestry firms, Chilean nationalism, and police malpractice, all interlock here as potential fuelers and justifications for further violence. While the positive public reputation of Carabineros has protected the police from high-level political criticism and reform, a combination of corruption scandals within the force and escalating social conflicts since 2006 has damaged its social standing. Most notably, the large number of demonstrators' deaths and mutilations after the social revolt in 2019, which prompted numerous condemning reports from international press and organizations (e.g., United Nations, 2019), has led some to recently discuss "refounding" or even dissolving Carabineros de Chile (El Mostrador, 2020).

Chile is therefore a good case to explore police violence in the context of a highly hierarchical society with violence being excessively applied against minority group members. The structure of the rest of the paper is as follows. We first discuss literature on support for police violence. We then relate research on support for police violence to work into punitive attitudes. We make the case that police excessive use of force - particularly when applied against minority group members - could usefully be understood as police violence as punishment. We discuss different motivations that might lay at the basis of such punishment, particularly the extent to which police repression of minorities can help restore status and power hierarchies perceived to be threatened by crime. A number of studies have looked at the antecedents of attitudes towards police use of force (e.g. Gerber \& Jackson 2017), extralegal punishment (e.g. Nivette, 2016) and legal punishment (e.g. Gerber, forthcoming). Yet, we know little about how police violence compares to legal and extra-legal punishment (see Nivette, 2016).

We present the hypotheses of our research, we outline the methods used, and we report the main findings. We then discuss the findings in relation to police violence in the US and other places. We argue that understanding whether public support for excessive violence reflects a way of seeking punishment among police officers is relevant if we are to advance understanding of the motivations that encourage people to turn a deaf ear on human rights reports on police repression. We finish by drawing prevention and policy implications of our work.

\section{Support for police (excessive) violence}

Protocols authorize police officers to use force, but only the minimum amount of force appropriate according to the seriousness of the threat (Alpert \& Dunham, 2004; Prenzler, Porter, \& Alpert, 2013). Use of force is allowed when offenders pose an imminent threat to the police officer or to another, for example, or when there is probable cause indicating that the suspect has engaged in a crime involving the threat or the infliction of serious bodily harm (Perkins \& Bourgeois, 2006). It is in this context that police violence (where force is considered excessive) can be defined as "any amount of force...that cannot be accounted for under the auspices of lawful necessity in the line of duty" (Stinson, 2020: 14).

Research into support for police violence has shown a number of socio-demographic predictors, predominantly in the US. Studies have shown that minority group members are less supportive of police use of force than majority group members (Arthur \& Case, 1994; Barkan \& Cohn, 1998; Johnson \& Kuhns, 2009). According to Jefferis et al. (2011) these negative attitudes can be explained by negative experiences between the police and citizens in minority communities, as well as experiences reported through the media. Gender and educational levels have also been shown to predict support for police violence, with males (Barkan \& Cohn, 1998; Johnson \& Kuhns, 2009) and people with lower levels of education (Arthur \& Case, 1994) generally expressing higher approval of violence. Fear of crime and everyday experiences with crime may also be relevant factors. Yet, while it is plausible that people who feel personally at risk also tend to favour police use of force as a way of increasing social control (see Arthur \& Case, 1994), findings here are again limited and mixed. Barkan and Cohn (1998) report positive attitudes toward police violence among whites expressing fear of crime, but other studies have not found similar statistical effects. 
Previous research has also shown that police legitimacy partly reflects people's belief that the police rightfully monopolize force in society, and that this may help to 'crowd out' the belief that private violence is acceptable (Jackson et al. 2013). When people see the police as legitimate, they accept their right to not only dictate people's appropriate behavior (Tyler, 2006; Trinkner, 2019; Posch et al., 2020), but also for the police to dictate what they themselves can do in certain situations (Bradford et al., 2020). As Bradford et al. (2017: 615) argue: "Legitimacy is based in an important sense in 'right behavior,' but it may also serve to "make behavior right".

But there are limits: Gerber and Jackson (2017) and Bradford et al. (2017) found that people who saw the police as legitimate also tended to view police violence to be acceptable, but only when the actions fell within existing normative boundaries of behavior. Support for actions that breach normatively appropriate boundaries - such as excessive use of force - seemed to require an extra-legal justification that was, in the analysis of Gerber and Jackson (2017), partly ideological in nature. People high in right-wing authoritarianism (RWA) and social dominance orientation (SDO) tended to express stronger support for excessive police use of force. On the one hand, individuals high in RWA may approve of police use of excessive force because it serves to control social threats and increase security. On the other hand, individuals high in SDO may view excessive use of force as justified because it is commonly used against subordinate groups and it thus helps maintaining existing power hierarchies. These findings suggest that approval for excessive police violence might serve the goal of restoring status and power hierarchies perceived to be threatened by crime.

\section{Police violence as punishment}

The public is highly accepting of police officers' use of force when required by the seriousness of the situation or as a way of self-defense. Yet, approving of violence that exceeds what can be considered minimal to control a situation seems, on the face of it, to serve a different goal. We propose a new way of explaining public support for excessive use of force that distinguishes between "police violence for social control" and "police violence for punishment". This new conceptualization implies that both forms of violence differ not only in terms of quantity of violence, but also in that they seek different goals from the perspective of citizens. Beyond protecting citizens or avoiding harm to the police officers, excessive violence is punitive, in part because it serves to punish alleged offenders in a way that (brutally) sidesteps due process.

King and Maruna (2009) define punitive sentiment as the desire to see a greater number of people punished, for greater durations, and with increased severity. Under this broad definition, the concept of punitive attitudes is not limited by the legal status of the punishment, i.e. punishment could be conducted by legal (i.e., the courts or the police) or extra-legal (i.e., private citizens) actors. It is important, therefore, to distinguish between legal and extra-legal punishment. Legal punishment, on the one hand, corresponds to sanctions that are applied by state agents with the legal authorization to punish. In theory, modern legal punishment is characterized by proportionality and due process: punishment is assigned in impartial ways, through accountable procedures, and (most of the time) does not involve using physical violence. Punitive policies range from capital punishment to mandatory sentencing to increasing the authority of law enforcement officials (Ramirez, 2013). On the other hand, extra-legal punishment -also referred to as vigilantism or lynching- is a form of informal norm enforcement which is "committed by private persons, usually in the form of corporal punishment or violence, against a perceived perpetrator" (Nivette, 2016: 143). There is, though, a third case of particular relevance: punishment can be conducted by law enforcement actors who do not hold the power to decide and apply this punishment (i.e., police officers). This is what we here define as police violence for punishment.

Two perspectives explain people's desires for punitive responses (Carlsmith et al., 2002; Darley \& Pittman, 2003; Gerber, forthcoming; Tyler \& Boeckmann, 1997; Vidmar \& Miller, 1980; Wenzel \& Thielmann, 2006): utilitarian (instrumental or consequentialist) perspective and retributive (moral) perspective. According to an utilitarian perspective, punishment is a means to reduce the likelihood of future harm for society. Assuming that offenders and citizens are rational actors, punishment should be applied in a way that is just sufficient to control the offender's behavior (Carlsmith et al., 2002). To control the behavior of current or potential offenders, general deterrence (i.e., setting an example to deter possible offenders from committing future crime), specific deterrence (i.e., deter the offender from reoffending), and incapacitation (i.e., removing offenders from society, usually through prison sentences) are applied. 
While some research has found relationships between punitive attitudes and deterrence beliefs (Steele \& Wilcox, 2003; Thomas \& Foster, 1975), fear of crime (Costelloe et al., 2009; De Keijser \& Elffers, 2009), victimization (Applegate et al., 2000), and concerns about crime (Costelloe et al., 2009; De Keijser \& Elffers, 2009), other research has found no relationship with victimization experiences (Costelloe et al., 2009; Cullen et al., 1985; King \& Maruna, 2009), personal fear of crime (Gerber \& Jackson, 2016; Sprott, 1999), and crime concerns (Cullen et al., 1985; King \& Maruna, 2009). Studies that have found more consistent link between punitive sentencing and non-crime related factors (Darley, 2009; Darley \& Pittman, 2003; King \& Maruna, 2009; Lerner et al., 1998; Tyler \& Boeckmann, 1997) suggest that there is more to punishment than utilitarianism.

According to the retributive perspective, punishment is not so much about preventing future crimes but about the retaliation of wrongful acts (Carlsmith et al., 2002; Darley \& Pittman, 2003; Vidmar \& Miller, 1980; Wenzel \& Okimoto, 2016). Retribution is the belief that criminal offenders deserve to be punished for the violation of common rules. It is thus a moral phenomenon concerned with the repayment of wrongful acts (Durkheim, 1964, 1973; Van Prooijen, 2018) and with achieving justice: If an offender violates norms, punishment should restore justice. Consistent with a retributive perspective, research has shown that the seriousness of the offense (Darley, 2009; Darley et al., 2000), concerns about social cohesion and moral decline (Tyler \& Boeckmann, 1997), moral outrage (Darley, 2009; Darley \& Pittman, 2003; Lerner et al., 1998), and generational and economic anxieties (King \& Maruna, 2009) predict support for stronger punitive responses.

Retributive responses have been further divided in two motivations: value restoration and status and power restoration (Vidmar \& Miller, 1980; Wenzel \& Thielmann, 2006). From a value-restoration perspective, crime threatens social and moral order, while punishment restores people's faith in common values by symbolically labelling the offense as wrong (Durkheim, 1964, 1973). Tyler and Boeckmann (1997) found that concerns about social cohesion and the deterioration of the moral structure of society were more relevant predictors of punitiveness than concerns about crime (see also King \& Maruna, 2009; Gerber \& Jackson, 2013). Crucially for the current study, the motivation to restore values justifies retributive responses to crime, yet it does so respecting procedural fairness for criminal offenders (Gerber \& Jackson, 2013), as well as a restorative perspective on punishment (Wenzel et al., 2012; Wenzel \& Thielmann, 2006).

According to a status and power restoration motive, when someone commits a crime (s)he assumes superiority, takes advantage, and shows disrespect for the victim and society (Miller, 2001). Harsh punitive responses restore the status quo in society by degrading the offender's status and empowering the victim and society (Okimoto \& Wenzel, 2009; Vidmar \& Miller, 1980; Wenzel \& Thielmann, 2006). Interestingly, in contrast to a value restoration motive, status and power motivations lead to justifying the denial of procedural fairness in the treatment of criminal offenders (Gerber \& Jackson, 2013). This perspective speaks directly to literature on how crime and punishment serve the function of maintaining the power of dominant groups by being unequally distributed and reducing the disadvantaged groups' opportunities even further (Garland, 1990; Wacquant, 2009; Western, 2006). In this paper we reason that police violence for punishment is particularly suited to address the status and power restoration motive as it degrades the offender's status by exceeding use of force and stepping outside of the boundaries of due process.

Extra-legal punishment (e.g., vigilantism or lynching) might also serve to restore the power of dominant groups; it does not follow accountable procedures and is often more violent than legal punishment. Physical force applied by private citizens to control crime are proscribed in most modern states, unless it is justified by self-defense. Thus, supporting extra-legal punishment implies punishing alleged wrongdoers at the expense of breaking the law. Traditionally it is assumed that there is a substitution relationship between private citizens and the state in the use of physical force for social control. In other words, if people take "justice into their own hands" it is because the state does not provide effective measures to reduce criminality. From this perspective, past experiences of victimization and a poor evaluation of the effectiveness of the criminal justice system play a key role in explaining support for mob violence as extra-legal punishment. Some research suggests a connection between people's perceptions of law enforcement and support for vigilante justice (Goldstein, 2012; Silke, 2001). Tankebe (2009) reported that perceptions of low police trustworthiness were the main driver of support for vigilantism in Ghana. However, neither the perceived effectiveness nor the perceived quality of police decision-making predicted support for vigilantism. Jackson and his 
colleagues (2013) reported similar findings in London: neither procedural justice nor police effectiveness explained people's willingness to use violence to settle disputes. Instead, what mattered was people's sense of obligation to obey the police, a measure of police legitimacy (see also Haas, de Keijser, \& Bruinsma, 2014). Contrastingly, Nivette (2016) analyzed data from 18 Latin American countries finding that perceived police criminality and institutional ineffectiveness predicted approval for vigilantism.

\section{This study}

Building on the above literature, our goal in this paper is to link scholarship on support for police violence and punitiveness to propose that excessive police violence can serve the aim of punishing crime, apart from controlling it. We explore the relationships between attitudes towards police violence for social control and police violence for punishment with the support for two forms of punishment: legal and extra-legal punishment. We reason that support for police violence as punishment requires to allow police officers to exceed their attributions for the use of power, resembling an extra-legal form of punishment more than police violence as social control. We thus hypothesize that support for police violence for punishment will be strongly related to support for extra-legal punishment $\left(\mathrm{H}_{1 \mathrm{a}}\right)$ and less strongly related to support for police violence for social control $\left(\mathrm{H}_{1 b}\right)$.

We then examine the motivations that underlie support for police violence for punishment and compare these to the motivations for legal and extra-legal punishment. We argue that police violence for punishment oversteps the boundaries of legal use of violence and as such denies criminal offenders the right for procedural fairness in their sentencing. The denial of procedural fairness in the treatment of criminal offenders has been shown to serve the function of humiliating and degrading offenders (Gerber \& Jackson, 2017). We therefore expect that support for police violence for punishment will be related to the motivation to restore status and power relations $\left(\mathrm{H}_{2 \mathrm{a}}\right)$ and unrelated to the motivation for deterrence $\left(\mathrm{H}_{2 \mathrm{~b}}\right)$ and value restoration $\left(\mathrm{H}_{2 \mathrm{c}}\right)$. Since extra-legal punishment does also not follow due process in the assignment of punishment, we expect the pattern of relationships between motivations to punish and support for police violence for punishment to be similar to the pattern of relationships with extra-legal punishment $\left(\mathrm{H}_{3 \mathrm{a}}\right)$ and different from the pattern of relationships with legal punishment $\left(\mathrm{H}_{3 \mathrm{~b}}\right)$. Finally, we consider the role of ethnic minorities as frequent victims of police violence. We reason that ethnic minority members should be less supportive of violence that is aimed at maintaining their own position as an oppressed group $\left(\mathrm{H}_{4}\right)$.

\section{Sample}

\section{Method}

This study draws on a survey conducted by Universidad Diego Portales (Chile) to capture a range of different attitudes about citizen's support for police action and their effectiveness, support for legal and extra-legal punishment, and punishment motivations. A representative sample of the adult population living in Chile completed a face-to-face questionnaire between September and October 2015. The survey used a stratified multistage sample design with random selection at every stage, achieving a total of 1,302 respondents ( $50 \%$ female, mean age $=47.9,8 \%$ with indigenous background).

\section{Measures}

Support for police violence for punishment was measured using a scenario that describes police officers catching a man who was trying to mug a woman. Responders rated their agreement with the police officers beating the detained offender up inside the police vehicle ( $24 \%$ agree) and taking the offender's clothes off, mocking and insulting him at the police station (16\% agree). For this and all other attitude items a scale ranging from $1=$ completely disagree to $5=$ completely agree was used. The correlation between both items was significantly positive $(\mathrm{r}=0.72, \mathrm{p}<0.01)$

Support for police violence for social control was measured using the same scenario but asking people to rate their agreement with police officers beating an offender up as a means to arrest him $(50.5 \%$ agree).

Support for legal punishment was measured asking respondents' level of agreement with the statements "Every person committing an assault should receive a prison sentence, with no exception" ( $81 \%$ agree), "Judges should give much longer sentences to those who have committed assaults" ( $80 \%$ 
agree) and "Those imprisoned for assaults should not have the right to reduce their sentence time for good behavior" (68\% agree). The three items were strongly correlated among each other $(a=0.81)$

Support for extra-legal punishment was measured using a scenario where people catch a man trying to mug a person on the street. Respondents were asked to state their level of disagreement or agreement with two statements describing people's reaction to the mugging: tying the offender to a lamppost and taking his clothes off (33\% agree), and beating him up (33\% agree). The correlation between both items was positive and significant $(\mathrm{r}=0.72, \mathrm{p}<0.01)$

Motivation for deterrence was measured asking respondents the degree to which they agreed with the following three statements: "Strongly punishing an offender will make him think twice before committing another crime", "If criminals are harshly punished, fewer people will try to commit crimes in the future" and "In the long run, punishing criminals harder will bring more security for all". The three items were strongly correlated among each other $(\mathrm{a}=0.89)$

Motivation for norm restoration was measured using three items: "Strongly punishing criminals shows that we are all united against crime", "Strongly punishing criminals demonstrates that rules exist and must be respected" and "A well-integrated society must punish those who commit crimes harshly". The three items were strongly correlated among each other $(\mathrm{a}=0.91)$

Finally, motivations for status and power restoration was measured using three items: "It is important that punishments humiliate the offender", "Criminals must be punished harshly to put them back in the place where they belong" and "A strong punishment shows the offender who really has the power". The three items were strongly correlated among each other $(a=0.79)$

We also control for Effectiveness of the police and judges (measures often used as control when predicting public support for police action, e.g., Gerber \& Jackson, 2017). Effectiveness of the police was measured by asking respondents their level of agreement with the statement "The police has the crime problem under control in Chile". Effectiveness of judges was measured with the statement "In Chile, judges condemn those who have to be condemned, and free those who must be free". Finally, six socio-demographic variables were considered as controls: gender ( $50 \%$ men); age (Min=18, Max=89, $\mathrm{M}=48, \mathrm{SD}=18$ ); ethnicity ( $8 \%$ indigenous); educational level (34\% Middle school or less, $43.9 \%$ high school graduate (42\%), 11\% technical and professional education and $13 \%$ with university degree); socio-economic status ( $88 \%$ low and middle status and $12 \%$ middle-high status) and political identification ( $16 \%$ left leaning; $12 \%$ center, $8 \%$ right leaning and $65 \%$ with no identification).

\section{Analyses}

We first examine correlations among both forms of police violence, legal and extra-legal punishment. We then estimate structural equation models analyzing the effect of motivations for punishment on police violence for punishment, legal punishment and extra-legal punishment. For this we consider dependent variables and motives of punishment as latent variables (except for police violence for social control, which is a single item). The models are fitted using maximum likelihood estimators with robust standard errors in lavaan version 0.6.7 (Rosseel, 2012).

\section{Results}

Table 1 displays correlations between police violence, extra-legal punishment and legal punishment. Support for police violence for punishment was positively and significantly correlated with support for police violence for social control $(r=.50, p<.01)$, and even more so with extra-legal punishment $(r=$ $.63, p<.01)$. Police violence for social control $(r=.26, p<.01)$ and extra-legal punishment $(r=.21, p$ $<.01)$ were both significantly although moderately correlated with legal punishment. Police violence for punishment, however, had a very small correlation with legal punishment $(r=.09, p<.01)$.

\section{- Table 1 around here -}

Table 2 illustrates a summary of the regression models with latent variables predicting police violence for punishment, extra-legal punishment and legal punishment. The model had a good fit according to standard criteria $(\chi 2(245)=694.13, \mathrm{p}<0.01 ; \mathrm{CFI}=0.964 ; \mathrm{RMSEA}=0.0 .041 ; \mathrm{SRMR}=0.040)$. The motivation to punish to deter crime $(\beta=.36, p<.05)$ and to restore power and status $(\beta=.42, p<$ .01 ) had positive associations with support for police violence for punishment, while the motivation to restore norms had a negative association $(\beta=-.51, p<.05)$. This pattern of relationships is very similar to the one found for extra-legal punishment, with positive relations to deterrence $(\beta=.40, p<.05)$ and power and status restoration $(\beta=.50, p<.01)$ and a negative association with norms restoration $(\beta=-$ 
$.51, p<.01)$. Finally, the pattern of motivations relevant to predict legal punishment was different: the most relevant predictor was norm restoration $(\beta=.67, p<.01)$, followed by a smaller positive association with status and power restoration $(\beta=.19, p<.01)$. Deterrence was negatively related to legal punishment $(\beta=-.39, p<.05)$ once the other motivations to punish were controlled for.

Police violence for punishment was also less approved among people from ethnic minorities $(\beta$ $=-.07, p=.01)$ and among people politically identified with the left as compared to no political identification $(\beta=-.07, p<.05)$. Finally, perceived police effectiveness was positively related to police violence for punishment $(\beta=.14, p<.01)$, a pattern that again resembles the relationship with extralegal punishment.

\section{- Table 2 around here -}

\section{Discussion}

In this paper we have examined the relationships between police violence as social control, police violence as punishment, extra-legal punishment, and legal punishment with different motivations to punish. We have presented evidence consistent with a strong relationship between support for police violence as punishment and support for extra-legal punishment $\left(\mathrm{H}_{1 \mathrm{a}}\right)$. The relationship with police violence for social control was smaller, as predicted $\left(\mathrm{H}_{1 b}\right)$ - yet still statistically significant. The latter might be explained by both dimensions expressing support for the police. But it is also possible that, in a country with longstanding and increasing police brutality, violence for social control has started to resemble violence for punishment. These findings might suggest a legitimization of excessive use of force by the police, at least in the eyes of some people in Chile.

In line with our second hypothesis, we found that police violence for punishment was related to the motivation to restore status and power $\left(\mathrm{H}_{2 \mathrm{a}}\right)$. Against expectations, it also had a positive association with deterrence $\left(\mathrm{H}_{2 \mathrm{~b}}\right)$ and a negative association with norm restoration $\left(\mathrm{H}_{2 \mathrm{c}}\right)$. These findings are relevant as they suggest that police violence as punishment serves to exclude criminal offenders from society. Criminal offenders are to be "put back into the place they belong" even at the cost of a lack of concern for the restoration of norm in society.

Consistent with our third hypothesis, the pattern of motivations for supporting police violence for punishment was clearly similar to the pattern for supporting extra-legal punishment $\left(\mathrm{H}_{3 \mathrm{a}}\right)$, while rather different from the pattern for supporting legal punishment $\left(\mathrm{H}_{3 \mathrm{~b}}\right)$. The main difference was that police violence for punishment and extra-legal punishment exhibited a negative relationship with value restoration, while the latter was positive in the case of legal punishment. Police violence for punishment and extra-legal punishment converge in stepping outside of the boundaries of legal use of violence (either by part of citizens or the police). By disrespecting due process for sentencing procedures, they deny procedural fairness towards criminal offenders. As has been shown in previous research (Gerber \& Jackson, 2013), denying procedural fairness is one way in which status and power hierarchies can be symbolically restored.

Finally, the results also indicate that respondents who identified with an ethnic minority reported lower support for police violence as punishment compared to people who are not part of an ethnic minority. $\left(\mathrm{H}_{4}\right)$. On the one hand, this fits with the strong status motivation behind such violence: oppressed groups such as ethnic minorities are likely less motivated to reinforce social hierarchy because it goes against their own self-interest. On the other hand, these findings highlight the relevance of regarding police violence towards ethnic minorities, and the relationship between police violence and racism. In Chile, the experiences of ethnic minorities with the police are systematically different from the experiences of other people. This is not surprising when we consider the colonial roots of the Chilean police and the systematic and persistent violence of the institution towards the First Nations of the territory. Similar to the police in the US, which has its roots in slave patrols (Hansford, 2016), the Chilean police was derived from the 'Gendarmes for the Colonies', an organization crated by the Chilean goverment during the XIX century for the invasion of indigenous lands and the genocide of its people (Palma, 2019). Acknowledging the historically driven relationship between a police force and different groups of people living in a specific territory is crucial to understand possible power relations underlying patterns of police use of violence. In our current research, the disadvantaged position of ethnic minority group members towards police officers in Chile is key to understanding the goals that police violence might serve. 


\section{Limitations}

In this paper we have focused on Chile, a country with a long and persistent history of police repression towards ethnic minorities and political dissenters. It is, however, an empirical question whether these findings might translate to other contexts. We can only speculate, but it may be that the political polarisation that is often found in the US, for example, means that some people support excessive police use of force against certain groups because they view those groups as threatening social hierarchies, and they believe that the application of violence serves to punish those groups for presenting such a threat. Some people against the Black Lives Matter movement (and for the Blue Lives Matter) might be motivated to express a "will to punish". It is for further research to replicate the current study across different countries.

Also, more research should be conducted to extend our incipient distinction between police violence for social control and police violence for punishment in a multidimensional manner. We have shown that these two theoretically different concepts diverge also empirically in their motivation patterns, yet a more robust measurement development and test is still missing.

Finally, as is often the case when observing associations between different punitive attitudes and support for violence, the strong relationship between police violence for punishment and extra-legal punishment might be explained by the higher levels of aggressiveness represented by both. Future research should control for trait aggressiveness or for the aggressiveness in the items that capture different forms of punishment.

\section{Prevention and policy implications}

Our findings have relevant prevention and policy implications. First, exploring the motivations underlying support for violence allows us to make policy decisions with more understanding of the content of the response to perceived harm. Understanding where the "will to punish" comes from is key to unravel the motivations underlying discourses installed in public opinion where it is assumed that punishing reduces violence and crime (deterrence) and is equivalent to "doing justice". Understanding the motivations at the base of violence and punishment is crucial to work towards preventing police repression against minorities.

In our research, the relevance of the motivation to restore status and power restoration in explaining public support for police violence for punishment suggests that reducing police violence against minorities requires a political and cultural process well beyond reforming police protocols and procedures; it requires addressing historical hierarchical differences between police officers and citizens in general, on the one hand, and alleged criminal offenders, on the other hand. A more horizontal view of society and advancing in improving intergroup relations between police officers and specific minority groups should reduce perceived needs to restore power and status relationships, hereby reducing support for police violence as punishment. Since the latter tend to be the most excessive forms of violence, reducing its support might reduce violence more generally, limiting it to a reasonable amount needed to maintain social order and defend citizens from actual threats. Reducing status and power differentials between police officers, citizens in general and minority group members might also reduce the perceived need to punish those generally disadvantaged groups in society, hereby reducing discretionality and discrimination in the application of violence. More generally speaking, any intervention seeking to reduce the framing of police officers and citizens as opposing groups might also reduce the need to reinforce status and power boundaries.

Second, the results presented here suggest that the implementation of harsher sentences is not likely to reduce support for extra-legal punishment or punitive police violence. On the contrary, repressive measures often have an (undesired) effect of validation of further punitive dispositions. An example of this are the anti-immigrant laws that have been accompanied by an increase in violence and hate crimes against immigrants by private citizens (see Flores, 2017). In a similar vein, previous research in Chile has shown that ethnic minorities that perceive low levels of procedural justice in the treatment they receive from police officers tend to increase their approval for violent ways to regain access to land and other benefits (Gerber et al., 2018). Therefore, insisting on policies that increase the authority and resources of law enforcement agencies or the penal system at the expense of policies that target the social causes of crime could serve as validation not only for the use of police violence as social control, but for the use of punitive police violence. 


\section{References}

Adriaenssen, A., \& Aertsen, I. (2015). Punitive attitudes: Towards an operationalization to measure individual punitivity in a multidimensional way. European Journal of Criminology 12(1), 92-112. https://doi.org/10.1177/1477370814535376

Arthur, J. A., \& Case, C. E. (1994). Race, class and support for police use of force. Crime, Law and Social Change, 21(2), 167-182.

Alpert, G. P., \& Dunham, R. G. (2004). Understanding police use of force: Officers, suspects, and reciprocity. Cambridge University Press.

Barkan, S. E., \& Cohn, S. F. (1998). Racial prejudice and support by whites for police use of force: A research note. Justice Quarterly, 15(4), 743-753.

Bonner, M. D. (2013). The Politics of Police Image in Chile. Journal of Latin American Studies, 45, 669-694.

Bonner, M. D. (2014). Policing Protest in Argentina and Chile. Lynne Reinner Pubs.

Bradford, B, Milani, J. \& Jackson, J. (2017). Identity, legitimacy and 'making sense' of police use of force. Policing: An International Journal of Police Strategies \& Management, 40(3), 614-27.

Bradford, B., Yesberg, J., Jackson, J. \& Dawson, P. (2020). Live Facial Recognition: Trust and Legitimacy as Predictors of Public Support for Police Use of New Technology, British Journal of Criminology, 60(6), 1502-1522. https://doi.org/10.1093/bjc/azaa032.

Carlsmith, K. M., Darley, J. M., \& Robinson, P. H. (2002). Why do we punish? Deterrence and just deserts as motives for punishment. Journal of Personality and Social Psychology, 83(2), 284-299. https://doi.org/10.1037/0022-3514.83.2.284

Costelloe, M. T., Chiricos, T., \& Gertz, M. (2009). Punitive attitudes toward criminals. Punishment \& Society, 11(1), 25-49. https://doi.org/10.1177/1462474508098131

Cullen, F. T., Clark, G. A., Cullen, J. B., \& Mathers, R. A. (1985). Attribution, salience, and attitudes toward criminal sanctioning. Criminal Justice and Behavior, 12(3), 305-331. https://doi.org/10.1177/0093854885012003003

Dammert, L. (2009). Police and Judicial Reform in Chile. In N. Uildriks (ed.), Policing Insecurity (pp. 151-68). Lanham, MD.

Darley, J. M., \& Pittman, T. S. (2003). The psychology of compensatory and retributive justice. Personality and Social Psychology Review, 7(4), 324-336. https://doi.org/10.1207/S15327957PSPR0704_05

Darley, J. M. (2009). Morality in the law: The psychological foundations of citizens' desires to punish transgressions. Annual Review of Law and Social Science, 5(1), 1-23. https://doi.org/10.1146/annurev.lawsocsci.4.110707.172335

Darley, J. M., Carlsmith, K. M., \& Robinson, P. H. (2000). Incapacitation and just deserts as motives for punishment. Law and Human Behavior, 24(6), 659-683. https://doi.org/10.1023/A:1005552203727

De Keijser, J. W., \& Elffers, H. (2009). Punitive public attitudes: A threat to the legitimacy of the criminal justice system. In M. E. Oswald, S. Bieneck, \& J. Hupfeld-Heinemann (Eds.), Social psychology of punishment of crime (pp. 55-74). John Wiley \& Sons.

Durkheim, É. (1964). The division of labor in society (G. Simpson, Trans.). Free Press, Collier (Original work published 1893).

Durkheim, É. (1973). Moral education: A study in the theory and application of the sociology of education (E. Wilson, \& H. Schnurer, Trans.). Free Press (Original work published 1925).

El Mostrador (2020). La tarea urgente de refundar Carabineros. Available at: https://www.elmostrador.cl/destacado/2020/11/20/la-tarea-urgente-de-refundar-carabineros/

Flores, R. D. (2017). Do anti-immigrant laws shape public sentiment? A study of Arizona's SB 1070 using Twitter data. American Journal of Sociology, 123(2), 333-384.

Fuentes, C. (2005). Contesting the Iron Fist. Routledge.

Garland, D. (1990). Punishment and modern society. University of Chicago Press. https://doi.org/10.7208/chicago/9780226922508.001.0001

Gerber, M. M. (forthcoming). Attitudes toward punishment. In H. Pontell (Ed.), Oxford Research Encyclopedia of Criminology and Criminal Justice. https://oxfordre.com/criminology/view/10.1093/acrefore/9780190264079.001.0001/acrefore978081090264079-e-640 
Gerber, M. M., \& Jackson, J. (2013). Retribution as revenge and retribution as just deserts. Social Justice Research, 26(1), 61-80. https://doi.org/10.1007/s11211-012-0174-7

Gerber, M. M., \& Jackson, J. (2016). Authority and punishment: On the ideological basis of punitive attitudes towards criminals. Psychiatry, Psychology and Law, 23(1), 113-134.

Gerber, M. M., \& Jackson, J. (2017). Justifying violence: Legitimacy, ideology and public support for police use of force. Psychology, Crime \& Law, 23(1), 79-95. https://doi.org/10.1080/1068316X.2016.1220556

Gerber, M. M., Gonzalez, R., Carvacho, H., Jimenez-Moya, G., Moray, C. and Jackson, J. (2018). On the Justification of Intergroup Violence: The Roles of Procedural Justice, Police Legitimacy and Group Identity in Attitudes towards Violence among Indigenous People. Psychology of Violence, 8(3), 379-389, doi: org/10.1037/vio0000177.

Goldstein, D. M. 2012. Outlawed: between security and rights in a Bolivian city. Durham: Duke University Press.

Haas, N. E., de Keijser, J. W., \& Bruinsma, G. J. (2014). Public support for vigilantism, confidence in police and police responsiveness. Policing and Society, 24(2), 224-241.

Hansford, J. (2016). Community Policing Reconsidered: From Ferguson to Baltimore. Policing the planet: Why the policing crisis led to black lives matter, 215-225.

Hathazy, P. (2013). Fighting for a Democratic Police. Comparative Sociology, 12, 505-547.

Jackson, J., Aziz, H., Bradford, B., \& Tyler, T. (2013). Monopolizing force? Police legitimacy and public attitudes toward the acceptability of violence. Psychology, Public Policy and Law, 19, 47997.

Johnson, D., \& Kuhns, J. B. (2009). Striking out: Race and support for police use of force. Justice Quarterly, 26(3), 592-623.

King, A., \& Maruna, S. (2009). Is a conservative just a liberal who has been mugged? Exploring the origins of punitive views. Punishment \& Society, 11, 147-169.

Lerner, J. S., Goldberg, J. H., \& Tetlock, P. E. (1998). Sober second thought: The effects of accountability, anger, and authoritarianism on attributions of responsibility. Personality \& Social Psychology Bulletin, 24(6), 563-574. https://doi.org/10.1177/0146167298246001

Martínez-Navarrete, E. (2020). Insurrección en Chile. LASA Forum 51(1), 72-76.

McKee, I. R., \& Feather, N. T. (2008). Revenge, retribution, and values: Social attitudes and punitive sentencing. Social Justice Research, 21(2), 138-163.

Miller, D. T. (2001). Disrespect and the experience of injustice. Annual Review of Psychology, 52, 527-553. https://doi.org/10.1146/annurev.psych.52.1.527

United Nations (2019). Informe sobre la Misión a Chile 30 de octubre - 22 de noviembre de 2019. Available at https://www.ohchr.org/Documents/Countries/CL/Report_Chile_2019_SP.pdf

Nivette, A. E. (2016). Institutional ineffectiveness, illegitimacy, and public support for vigilantism in Latin America. Criminology, 54(1), 142-175.

Palacios-Valladares, I. (2020). Chile's 2019 October Protests and the Student Movement. Revista de Ciencia Política, 40(2), 215-234.

Palma, D. (2019). Policías rurales en Chile: los Gendarmes de las Colonias, 1896-1907. Claves. Revista De Historia, 3(4), 105-134. https://doi.org/10.25032/crh.v3i4.133

Posch, K., Jackson, J., Bradford, B. \& MacQueen, S. (2020). 'Truly Free Consent'? Clarifying the Nature of Police Legitimacy using Causal Mediation Analysis. Journal of Experimental Criminology. https://doi.org/10.1007/s11292-020-09426-x.

Prenzler, T., Porter, L., \& Alpert, G. P. (2013). Reducing police use of force: Case studies and prospects. Aggression and Violent Behavior, 18(2), 343-356.

Ramirez M. D. (2013). Punitive Sentiment. Criminology, 51(2), 329-364.

Rosseel, Y. (2012). Lavaan: An R package for structural equation modeling and more. Version 0.5-12 (BETA). Journal of Statistical Software 48(2), 1-36.

Schwartz, G. L., \& Jahn, J. L. (2020). Mapping fatal police violence across U.S. Metropolitan areas: Overall rates and racial/ethnic inequities, 2013-2017. PLOS ONE, 15(6), e0229686. https://doi.org/10.1371/journal.pone.0229686

Silke, A. (2001). Dealing with Vigilantism: Issues and Lessons for the Police. Police Journal, 74, 120 $-133$. 
Steele, T., \& Wilcox, N. (2003). A view from the inside: The role of redemption, deterrence, and masculinity on inmate support for the death penalty. Crime \& Delinquency, 49(2), 285-312. https://doi.org/10.1177/0011128702251064

Stinson, P. M. (2020). Criminology explains police violence (Vol. 1). University of California Press.

Tankebe, J. (2009). Self-help, policing, and procedural justice: Ghanaian vigilantism and the rule of law. Law \& Society Review, 43, 245-70.

Thomas, C. W., \& Foster, S. C. (1975). A sociological perspective on public support for capital punishment. The American Journal of Orthopsychiatry, 45(4), 641-657. https://doi.org/10.1111/j.1939-0025.1975.tb01192.x

Trinkner, R. (2019). Clarifying the Contours of the Police Legitimacy Measurement Debate: A Response to Cao and Graham. Asian J. of Criminology, 14(4), 309-35.

Tyler, T. R., \& Boeckmann, R. J. (1997). Three strikes and you are out, but why? The psychology of public support for punishing rule breakers. Law \& Society Review, 31(2), 237 - 265. https://doi.org/10.2307/3053926

Tyler, T. R. (2006). Psychological Perspectives on Legitimacy and Legitimation. Annual Review of Psychology 57, 375-400.

Vidmar, N., \& Miller, D. T. (1980). Socialpsychological processes underlying attitudes toward legal punishment. Law \& Society Review, 14(3), 565-602. https://doi.org/10.2307/3053193

Wacquant, L. (2009). Punishing the poor: The neoliberal government of social insecurity. Duke university Press.

Wenzel, M., \& Okimoto, T. G. (2016). Retributive justice. In C. Sabbagh \& M. Schmitt (Eds.), Handbook of social justice theory and research (Vol. 26, pp. 237-256). Springer New York. https://doi.org/10.1007/978-1-4939-3216-0 13

Wenzel, M., Okimoto, T. G., \& Cameron, K. (2012). Do retributive and restorative justice processes address different symbolic concerns? Critical Criminology, 20(1), 25-44. https://doi.org/10.1007/s10612-011-9147-7

Wenzel, M., \& Thielmann, I. (2006). Why we punish in the name of justice: Just desert versus value restoration and the role of social identity. Social Justice Research, 19(4), 450-470. https://doi.org/10.1007/s11211-006-0028-2

Western, B. (2006). Punishment and inequality in America. Russell Sage. 
Table1

Correlation matrix among attitudes towards police violence, extra-legal violence and harsh sentencing (latent variables) $(n=1302)$

\begin{tabular}{llllll}
\hline & M & SD & 1 & 2 & 3 \\
\hline 1 Police violence for punishment & 2.39 & 1.07 & & & \\
2 Police violence for control & 3.26 & 1.23 & $.50^{* *}$ & & \\
& & & {$[.45, .54]$} & & \\
& & & & & \\
3 Extra-legal punishment & 2.77 & 1.20 & $.63^{* *}$ & $.48^{* *}$ & \\
& & & {$[.60, .67]$} & {$[.43, .52]$} & \\
4 Legal punishment & & & & & \\
& 3.99 & 0.86 & $.08^{* *}$ & $.26^{* *}$ & $.21^{* *}$ \\
& & & {$[.03, .14]$} & {$[.21, .31]$} & {$[.15, .26]$} \\
\hline
\end{tabular}


Table 2

Linear regression models predicting attitudes towards police violence por punishment, extra-legal punishment, and legal punishment $(n=1302)$

\begin{tabular}{|c|c|c|c|c|c|c|}
\hline & \multicolumn{2}{|c|}{$\begin{array}{c}\text { Police violence for } \\
\text { punishment }\end{array}$} & \multicolumn{2}{|c|}{$\begin{array}{c}\text { Legal } \\
\text { punishment }\end{array}$} & \multicolumn{2}{|c|}{$\begin{array}{l}\text { Extra-legal } \\
\text { punishment }\end{array}$} \\
\hline & St. coef & p & St. coef & $\mathbf{p}$ & St. coef & $\mathbf{p}$ \\
\hline \multicolumn{7}{|l|}{ Socio-demographic variables } \\
\hline $\operatorname{Sex}(1=$ Man $)$ & -0.003 & 0.918 & 0.021 & 0.479 & 0.032 & 0.303 \\
\hline Age & 0.040 & 0.215 & -0.032 & 0.311 & 0.039 & 0.231 \\
\hline Ethnicity (1=Ethnic minority) & -0.074 & 0.007 & 0.062 & 0.011 & -0.032 & 0.285 \\
\hline \multicolumn{7}{|l|}{ Education level (ref: middle school or less) } \\
\hline High school graduate & 0.030 & 0.436 & -0.088 & 0.010 & -0.047 & 0.220 \\
\hline Technical and professional education & -0.049 & 0.132 & 0.036 & 0.224 & -0.045 & 0.206 \\
\hline College or more & 0.019 & 0.627 & -0.027 & 0.462 & -0.011 & 0.770 \\
\hline Socio-economic status $(1=\mathrm{High})$ & -0.008 & 0.841 & -0.021 & 0.549 & -0.016 & 0.658 \\
\hline \multicolumn{7}{|c|}{ Political identification (ref: no identification) } \\
\hline Right & -0.000 & 0.999 & 0.009 & 0.711 & 0.010 & 0.756 \\
\hline Center & -0.058 & 0.063 & -0.015 & 0.652 & -0.094 & 0.002 \\
\hline Left & -0.074 & 0.024 & -0.051 & 0.112 & -0.073 & 0.022 \\
\hline \multicolumn{7}{|l|}{ Effectiveness } \\
\hline Police effectiveness & 0.144 & 0.000 & -0.016 & 0.596 & 0.135 & 0.000 \\
\hline Judges effectiveness & 0.022 & 0.517 & -0.135 & 0.000 & -0.025 & 0.449 \\
\hline \multicolumn{7}{|l|}{ Motives of punishment } \\
\hline Deterrence & 0.362 & 0.033 & -0.392 & 0.025 & 0.399 & 0.019 \\
\hline Norm restoration & -0.514 & 0.006 & 0.671 & 0.000 & -0.511 & 0.006 \\
\hline Power restoration & 0.419 & 0.000 & 0.194 & 0.005 & 0.496 & 0.000 \\
\hline R-square & \multicolumn{2}{|c|}{0,141} & \multicolumn{2}{|c|}{0,280} & \multicolumn{2}{|c|}{0,205} \\
\hline
\end{tabular}

Note. Model fit: $\chi 2(245)=694.13, \mathrm{p}<0.01 ; \mathrm{CFI}=0.964 ; \mathrm{RMSEA}=0.0 .041 ; \mathrm{SRMR}=0.040$. 